\title{
Chapter 10: Agri-Food Trade Between the United States and Russia: From Divergence to Irrelevance
}

\author{
Stephen K. Wegren
}

\section{INTRODUCTION}

Historically, the U.S.-Russia agricultural trade relationship has been onesided with the United States as the exporting country. Starting in the 1970s, the former USSR became a prominent importer of grain from the United States. For the remainder of the Cold War, even though the bilateral political relationship was tense, the United States supplied and even increased grain shipments to its adversary. Since August 2014, however, the U.S. has been almost entirely shut out of the Russian food market and its 146 million consumers due to Russia's embargo, called countersanctions. Although Russia's food embargo against the West has been widely discussed in the media and among scholars, the fact is that even prior to 2014, American agricultural exports to Russia already were already declining in dollar amount and quantity. Russia's 2014 food embargo

\footnotetext{
S. K. Wegren $(\bowtie)$

Department of Political Science, Southern Methodist University, Dallas, TX, USA

e-mail: swegren@smu.edu

(C) The Author(s) 2022

S. K. Wegren and F. Nilssen (eds.), Russia's Role in the Contemporary

International Agri-Food Trade System, Palgrave Advances

in Bioeconomy: Economics and Policies,

https://doi.org/10.1007/978-3-030-77451-6_11
} 
merely took the agricultural trade relationship with the U.S. one step further, to irrelevance.

This chapter examines whether political relations affect agricultural trade. It surveys bilateral agricultural trade between the United States and Russia, starting in the 1970s and continuing to the present. ${ }^{1}$ The Cold War period suggests that political relations do not need to affect food trade. The period since 2014 raises the question of whether it may be possible to re-start agricultural exports to Russia based on the Cold War precedent, or whether the post-Cold War pattern of convergence will continue.

This historical survey leads to several conclusions. First, during the Cold War, the link between the political relationship and food trade often was weak. In other words, political relations between the United States and Russia and agricultural trade were divergent, which means that agricultural exports were maintained or increased even as the political relationship deteriorated. Second, the divergence between worsening political relations and increasing agricultural exports ended in the postSoviet period. Instead, the relationship between politics and agricultural exports became convergent. With Putin in office, U.S. agricultural exports have fallen into irrelevance, a trend that predates 2014 but has become pronounced since 2014. To the extent that the U.S. ever had a 'food weapon' in its arsenal, this lever to influence Russian behaviour going forward would appear to be lost. The next section presents the analytical framework and subsequent sections examine the interplay between political relations and agricultural trade during the Cold War 1970s and 1980s, the 1990s, and since 2000.

\section{Analytical Framework}

The analytical framework draws ideas from two literatures. The first, Realism, holds that leaders act to ensure national security; national security is in turn is a function of power and power is a function of military strength. In short, national leaders are interested in maximising their own national security and minimising the strength of an adversary. The second literature argues that food may be weaponised to advance foreign policy interests and national security. States frequently use food to enhance power and when they do, government's food exports are utilised to gain economic, diplomatic, or security advantages. ${ }^{2}$ Paarlberg observes that with regard to diplomatic or security advantages, exporters may use food 
power to reward allies or punish adversaries with embargoes. Importers may adopt a defensive form of food power by reducing food imports or diversifying their imports away from an adversary. ${ }^{3}$

Intuitively, one would think that trade follows political relations. Indeed, Gowa argues that trade creates security externalities and for that reason, trade is more likely to occur within alliances than across alliances, especially in a bipolar world. ${ }^{4}$ That said, the fact is that the United States exported strategically important food to its rival the USSR during the Cold War. Broadly speaking, adversaries have different motivations for trading with one another. One side tries to initiate trade to lower tensions or to improve relations. The exporting side may want to create dependence by the importer and thus gain potential leverage. The importing side may want access to goods that it cannot produce itself or are cost-prohibitive to produce. That said, the core motivation of state security and preservation can also be threatened by international trade with adversaries. In agricultural trade, for example, exporting food allows that adversary to allocate resources to its military to make itself stronger instead of growing food. A state that imports food from an adversary helps its rival earn income that allows it to use that higher income for its military. A rise in disposable income in an adversary state thereby lessens the security of the first state.

Concerning bilateral relations between the United States and the USSR, American presidents from the beginning considered the Soviet regime to be illegitimate, but that does not mean that they were prepared to dedicate resources to force its overthrow or replacement. Gaddis argues that however distasteful the Soviet regime was, no U.S. president ever tried for regime change in the USSR, even going so far as to help Soviet leaders twice in their darkest hour. ${ }^{5}$ During 1921-1922, the United States offered food aid to the nascent Soviet government instead of working for the overthrow of Bolshevism; and in 1941, following Hitler's attack on the USSR, the United States sided with Stalin against Germany rather than try to bring Stalinism to an end. The question, therefore, is not merely why the United States did not press its advantage against its main adversary in the post-World War II period, but also why it did not take advantage of Soviet systemic weaknesses in later decades. In particular, it is curious why did the U.S. not utilise its 'food weapon' against a rival that suffered from chronic food shortages.

U.S. policymakers have been aware of their food power. The politicalisation of food trade dates has existed for decades. In the years following 
World War II, both food aid and commercial food sales were used repeatedly by the United States to support its foreign policy goals in different regions of the world. ${ }^{6}$ The politicalisation of food aid dates to the 1950s. The Eisenhower administration used food to exacerbate tensions between the communist regime in East Germany and its population following the death of Stalin in March 1953. ${ }^{7}$ In the early 1960s, the Kennedy administration advocated making 'full use of our agricultural abundance in furtherance of U.S. foreign policy'.

Commercial food sales were also politicised. In 1974, Secretary of Agriculture Earl Butz referred to food as a 'weapon' that the U.S. should utilise. In the early 1980s, conservative analysts in the U.S. recognised the disadvantaged position the Soviets were in and called for using American grain as leverage by threatening or actually withholding grain to change Soviet international behaviour and to make the USSR pay an economic price for violating international norms. ${ }^{9}$ Specifically, conservatives argued that the grain weapon could be used to force a reduction in Soviet livestock herds that ultimately would affect meat consumption levels, with the intent to foment consumers' dissatisfaction with the Soviet regime. Some evidence suggests that the food weapon was at least partially effective. Following the U.S. ban on grain sales to the USSR in 1980, the CIA noted 'a rising incidence of strikes related to food shortages in the 19801982 period', although the dysfunctional retail price and distribution system also contributed to spotty food supplies. ${ }^{10}$ Thus, it is reasonable to conclude that food exports are another weapon in states' arsenals to protect and project their interests.

\section{Cold War Foreign Policy Context: I970-1985}

Dating from 1946, the USSR and the United States were adversaries who during the next forty-five years would engage in espionage, assassinations, coups, and support puppet governments in an effort to gain a geopolitical advantage against the other. The Cold War represented economic, psychological, ideological, and geopolitical warfare, stopping just short of direct military conflict between the two countries. During the second half of the 1970s and into the 1980s the Soviet Union reached the apex of its global political influence and its military might. During this period there was a significant increase in Soviet military forces. The build-up included a dramatic increase in ICBMs; modernisation of the navy, including the deployment of submarines with nuclear warheads, 
nuclear-powered attack submarines, and an expansion in the number of guided missile cruisers, frigates, destroyers, and aircraft carriers; the development of intermediate nuclear weapons; the modernisation of ground forces and ground attack capability; the deployment of advanced strategic bombers and attack aircraft; and the development of air defences. The Soviet intent was to challenge U.S. hegemony on the land, sea, air, and in nuclear force. Improvements in Soviet military capability were also accompanied by the spread of political influence into Central America, North Africa, and the Middle East, an improvement in relations with India and China, and forging alliances with Vietnam and North Korea. ${ }^{11}$ By the late 1970s-early 1980s the USSR reached nuclear parity or even surpassed the United States based on sheer numbers of nuclear weapons and warheads. In short, the national security of the United States was threatened by Soviet advances militarily and politically.

Although the 1970s is sometimes called the 'decade of détente', in fact, it was at its height only during 1972-1974. By mid-decade, the détente relationship already showed signs of unraveling. Soviet support for rebels in regional conflicts such as Angola, Ethiopia, and Mozambique strained the relationship and in the opinion of U.S. leaders violated the 1972 political 'code of conduct'. Soviet pressure on Poland in the wake of widespread protests in 1976 led President Gerald Ford to stop referring to détente during his reelection campaign, reflecting the fact that conservatives were souring on détente and its supposed benefits. In 1979, the U.S. raised alarms that the Soviets were stationing combat troops in Cuba. Although in many ways that crisis was manufactured and did not constitute a new phase of Soviet adventurism in the Caribbean, it did cause enough of a ruckus as to prevent the SALT II Treaty from being approved in 1979, ${ }^{12}$ and following the Soviet's December 1979 invasion of Afghanistan, the treaty was removed from consideration in the Senate. The U.S. also raised objections over Soviet support for Sandinistas in Nicaragua that threatened American interests in Central America. The decade ended with the Soviet Union invading Afghanistan which at the time was feared by U.S. conservatives to be a drive to cut off the U.S. from Saudi oil. By the end of the 1970s, U.S. political willingness to cooperate with the USSR had waned.

The first half of the 1980s witnessed the Cold War at its coldest. There was a general war scare among the general population in both the U.S. and USSR. In the West, the peace movement ramped up as the superpowers seemed headed for conflict. President Ronald Reagan distrusted 
the Soviet leaders and accused them of being 'the focus of evil in the modern world' and being behind all of the global political instability that was occurring in different regions. ${ }^{13}$ Numerous crises exacerbated tensions: the imposition of martial law in Poland and a threatened Soviet invasion over the challenge represented by Solidarity to communist rule in 1980; the standoff over the deployment of U.S. medium-range missiles in Europe in 1982-1983; and the shooting down of a Korean passenger plane in August 1983. After August 1983 then-General Secretary Yurii Andropov indicated that he was done talking to the Americans. The Soviets stationed submarines armed with SLBMs off the East coast that could reach Washington, DC in less than ten minutes. Muscle-flexing in Berlin in 1984 led to the shooting death of an American soldier near the Berlin Wall.

The existential threat posed by Soviet nuclear forces in the early 1980s is easily forgotten today but was very real then. Coit Blacker noted that in the early 1980s the Soviets could devote 3,000-4,000 warheads from their SS17, SS18, and SS19 ICBMs that could destroy 90 percent of the U.S. ICBM force. He argued that 'the development of this Soviet option [to strike first] deeply disturbs some Western military and political leaders because....it enhances the Kremlin's ability to "intimidate" or to "coerce" the United States and its allies during times of severe tension or crisis". ${ }^{14}$ Such a strike would not only destroy U.S. retaliatory capacity but render its economy and society unable to function. Together with Secretary of State Alexander Haig, Reagan's intent was 'the management of global Soviet power', a strategy, which relied more on the stick than the carrot. ${ }^{15}$ In reaction to these trends, during Reagan's first term, the U.S. engaged in a significant military modernisation and introduced new nuclear landbased, sea-based, and air-based weapons to counter the Soviet military build-up. The Strategic Defence Initiative, or 'Star Wars' as it came to be called, was directed at the Soviet Union and threatened to neutralise its nuclear deterrent.

Despite a rising political and security threat, the United States sold wheat and feed grain to the adversary who threatened its survival. To be sure, rivals trade with each other during periods when they are not at war. ${ }^{16}$ That said, there had never been a global rivalry on the scale of the Cold War. Thus, Soviet-American bilateral food trade was paradoxical because the two nations were competing globally while simultaneously engaging in trade which helped the other country. 
The seeming paradox of American food exports to the country that most threatened it is compounded by two other factors. First, in the 1970s and 1980s, the U.S. was the global food hegemon, accounting for 55 percent of international wheat and coarse grain exports in $1980 .{ }^{17}$ France and Canada were second and third, respectively, accounting for 10 percent of global wheat and coarse grain exports in that same year. ${ }^{18}$ In other words, the U.S. had the food resources that could not be matched by any other country. It had the leverage, at least in theory, to disrupt Soviet society and foster political instability. In the current vernacular, the U.S. could have worked for regime change. Second, the U.S. had options about to whom to sell its surplus grain. The U.S. was not forced to sell grain to the Soviet Union. There were other potential and real customers besides the Soviet Union: Eastern bloc satellites were eager customers; surplus grain could be offered as concessionary food aid; or surplus grain could be commercially sold to developing nations. Members of OPEC in particular were interested in the purchase of American wheat. ${ }^{19}$ Thus, while the U.S. was interested in the economic advantages of exporting its surplus grain, there was nothing that dictated that the purchaser had to be the Soviet Union.

\section{U.S. Agricultural Exports to USSR, I972-I984}

When political relations and agricultural trade move in the same direction I refer to it as convergence; divergence occurs when political relations and agricultural trade move in opposite directions. The 1972-1985 period is an example of convergence (1972-1974) and then divergence (19751985), during which the political relationship deteriorated but U.S. agricultural exports to the USSR reached unprecedented levels in value and quantity.

\section{$4.1 \quad 1972-1974$}

In 1972, at the beginning of détente, former Secretary of State Henry Kissinger had wanted to cultivate Soviet dependence on U.S. grain and link trade to Soviet behaviour in Jewish emigration and other foreign policy. ${ }^{20}$ In the second half of the decade, that dependence certainly existed, but the U.S. did not deploy its food weapon to its political or security advantage. 
As political relations warmed in the early détente period, the United States extended a $\$ 750$ million USD Commodity Credit Corporation loan in 1972 to the Soviet Union to purchase U.S. grain. The agreement included an understanding that U.S. cargo ships would be used. ${ }^{21}$ The grain agreement required the Soviets to purchase a minimum of $\$ 200$ million USD in each year of the three-year deal. In reality, the Soviets utilised the entire $\$ 750$ million USD credit in year one by misrepresenting their true needs. Ultimately, in 1972 the Soviets purchased 25 percent of the American wheat harvest at subsidised prices, the largest grain purchase in history, as well as large quantities of corn and soybeans. ${ }^{22}$ The total purchase value exceeded \$1 billion USD. When the full extent of Soviet purchases became known, the Nixon administration was embarrassed and American consumers were faced with higher retail prices for bread. The deal became known as the 'great grain robbery'. ${ }^{23}$

In 1974, after another large Soviet purchase, and remembering the bad experience of 1972, President Gerald Ford canceled \$500 million USD in export contracts with the USSR in order to ensure sufficient domestic supply and to prevent further food inflation. ${ }^{24}$ As a result, the value of agricultural exports to the USSR dropped nearly 70 percent compared to 1973. Again in 1975, the U.S. government suspended export contracts with the Soviets during a record American wheat harvest. American farmers claimed that the export ban cost them \$200 million USD from lower domestic prices and lost business abroad. ${ }^{25}$ The 1975 suspension was short-lived, however, as farm states organised to oppose the move. Thus, the embargo lasted only two months and for all of 1975 the value of U.S. agricultural exports to the USSR jumped to over \$1.1 billion USD, beginning a string of years when agricultural sales surpassed $\$ 1$ billion USD.

\section{$4.2 \quad 1975-1984$}

Another poor Soviet harvest led to a new five-year deal in October 1975 to buy American grain (1976-1981). The agreement almost fell apart over the U.S. insistence on a long-term commitment which the Soviets initially rejected. ${ }^{26}$ The final agreement required that the Soviet Union purchase a minimum of six million metric tonnes $(\mathrm{mmt})$ of grain each year, evenly divided between corn and wheat. If U.S. production surpassed $225 \mathrm{mmt}$, the Soviets could buy up to $8 \mathrm{mmt}$ without consultation; above $8 \mathrm{mmt}$ required prior notification and permission from the 
Table 1 U.S. Agricultural Exports to USSR, 1975-1979 (dollar values are USD)

\begin{tabular}{cccc}
\hline & $\begin{array}{c}\text { Total value of U.S. } \\
\text { agricultural exports to } \\
\text { USSR }\end{array}$ & $\begin{array}{c}\text { Value of US grain } \\
\text { exports to USSR }\end{array}$ & $\begin{array}{c}\text { U.S. grain sales to USSR } \\
\text { (million metric tonnes) }\end{array}$ \\
\hline 1975 & \$1.17 billion & $\$ 1.13$ billion & 7.61 \\
1976 & $\$ 1.60$ billion & $\$ 1.46$ billion & 11.60 \\
1977 & $\$ 1.05$ billion & $\$ 852.5$ million & 6.86 \\
1978 & $\$ 1.76$ billion & $\$ 1.47$ billion & 13.44 \\
1979 & $\$ 3.00$ billion & $\$ 2.39$ billion & 18.87 \\
\hline
\end{tabular}

Source Kathryn A. Zeimetz, USSR Agricultural Trade, Statistical Bulletin 808 (Washington, DC: United States Department of Agriculture, Economic Research Service, 1991), 36, 38

U.S. government. ${ }^{27}$ In reality, the Soviets purchased much more than the minimum stipulated in the agreement. In 1976 they were allowed to purchase $11.6 \mathrm{mmt}$ of grain, $13.4 \mathrm{mmt}$ in 1978 , and $18.8 \mathrm{mmt}$ in 1979 without objection from the U.S. government. The dollar value of U.S. agricultural exports to the USSR during 1975-1979 is shown in Table 1.

The fact that agricultural trade did not suffer even as the détente relationship deteriorated after 1974 reflects divergence between politics and economics. Despite a rise in bilateral political tensions, U.S. agricultural exports to the USSR remained strong, surpassing \$1 billion USD each year during 1975-1979 and reaching \$3 billion USD in 1979. Ironically, both rivals helped each other. Soviet imports of American grain contributed to the rise of American food power. The U.S. share of world agricultural trade increased from 13.5 percent in 1970 to 17 percent in 1978. Moreover, during the 1970s the U.S. accounted for more than 80 percent of the increase in global grain exports. ${ }^{28}$ Conversely, American grain exports allowed the USSR to continue to allocate large amount of money and other resources to its military and towards expanding its influence around the world.

Thus, the second half of the 1970s witnessed divergence between political relations and agricultural exports, which meant that America's use of food as a weapon of foreign policy was weak and the deterioration in the political relationship became secondary to economic considerations. If U.S. security considerations had dominated, there certainly were available levers given the fact that U.S. grain accounted for over 60 percent of Soviet grain imports from 1972 through 1979. ${ }^{29}$ In the 1978/1979 
agricultural year, U.S. grain exports accounted for 67 percent of Soviet grain imports. ${ }^{30}$

The 1980s began with a U.S. grain embargo in retaliation for the Soviet invasion of Afghanistan. President Jimmy Carter suspended delivery of grain sales in December 1979 for purchases in excess of the 8 mmt permitted in the 1975 grain agreement. Paarlberg notes that 'never before had U.S. food exports to the USSR been suspended in pursuit of a noncommercial, foreign policy objective' ${ }^{31}$ It appeared that the 'food weapon' had been taken from the shelf.

The U.S. grain embargo was an important symbolic act, along with the U.S. boycott of the 1980 Olympics in Moscow. But the embargo was not successful. This occurrence in and of itself is not surprising since the literature on sanctions is generally negative about the effectiveness of sanctions. ${ }^{32}$ Lindsay places sanctions into five categories: (1) compliance-to alter another state's behaviour; (2) subversion-to remove the target's leaders; $(3)$ deterrence-to dissuade the target from repeating disputed behaviour in the future; (4) international symbolismto send a message to other members of the world community; and (5) domestic symbolism - to increase domestic support and thwart domestic criticism of its policies. ${ }^{33}$ Carter's grain embargo was most concerned with domestic symbolism and according to Paarlberg was not intended to force the Soviets out of Afghanistan but simply to punish them for their behaviour. ${ }^{34}$

The U.S. grain embargo was not successful for a variety of reasons. First, the U.S. was unable to enforce an embargo coalition and thus there was considerable 'leakage', meaning other states filled the U.S. void. Canada, Australia, Argentina, and the European Community all expanded their grain sales to the Soviet Union following the announcement of the U.S. embargo. Even India sold grain to the USSR for the first time, a modest $2 \mathrm{mmt}$. In short, the Soviet Union was able to substitute U.S. grain and thus paid a very small price for its 'adventurism' in Afghanistan. Second, the embargo motivated Soviet leaders to lessen their dependence on U.S. grain, although doing so proved more difficult. During the first half of the 1980s, the U.S. share of Soviet grain imports did not exceed 40 percent, compared to more than 60 percent in the 1970s. Third, the U.S. grain embargo was not expanded to Warsaw Pact countries to prevent 'leakage' to the USSR. Instead, the U.S. expanded grain sales to Eastern Europe from an original $16 \mathrm{mmt}$ to $18 \mathrm{mmt}$ despite favourable harvests in the communist bloc. ${ }^{35}$ 
Perhaps most important, the embargo did not even meet its limited goal of punishing the Soviets for their behaviour in Afghanistan. A longterm 'leak proof' embargo combined with a reduction in agricultural exports may have forced the Soviet leaders to reallocate resources away from the military, but that was not done for domestic political reasons in the U.S. Carter's embargo was designed to trigger a distress slaughter of livestock due to feed shortages, thereby affecting Soviet meat supply and consumption. Instead, in 1980 the Soviet Union fed $126 \mathrm{mmt}$ of grain to livestock, $1 \mathrm{mmt}$ more than the year before. ${ }^{36}$ In reality, there was no distress slaughter. In the Russian Republic during 1979-1984 the number of long-horned cattle rose from 58.6 million to 60 million head; the number of dairy cows remained constant at 22.2 million; and the number of pigs increased from 36.4 million to 38.7 million. ${ }^{37}$ Finally, in April 1981, four months into the new administration of Ronald Reagan, the arch-anti-communist, the U.S. embargo ended. ${ }^{38}$

The five-year period 1980-1984 period overall witnessed significant divergence between political relations, which fell to their nadir, and agricultural trade which increased. Instead of the U.S. maximising its leverage at a time when the enemy was vulnerable, the value of U.S. agricultural exports increased from $\$ 1.1$ billion USD in 1980 to $\$ 2.8$ billion USD in 1984. Even as the two sides threatened each other militarily, the volume of U.S. grain sales increased from $6.6 \mathrm{mmt}$ in 1980 to over $18 \mathrm{mmt}$ in 1984. Moreover, U.S. grain sales averaged $10.7 \mathrm{mmt}$ during 1980-1984, more than double the level of the détente years 1970-1974 when the political relationship warmed. During 1980-1984, the average annual value of America's agricultural exports to the Soviet Union was $\$ 1.80$ billion USD, higher than the $\$ 1.69$ billion USD average during 1975-1979, as shown in Table 2.

As the 1980s came to a close, U.S. agricultural exports to the USSR were at their peak. During 1988-1991 U.S. agricultural exports totaled more than $\$ 10.55$ billion USD, more than in any other four-year period. This high point in U.S. agricultural exports to the Soviet Union reflected the partial opening of the Soviet economy and improving bilateral political relations. During the 1988-1991 period, political relations and agricultural trade were convergent.

Rising American agricultural exports also reflected political support by the Reagan and Bush administrations for President Mikhail Gorbachev and his perestroika efforts, particularly in foreign policy where he was making unilateral concessions in Eastern Europe and supporting the U.S. 
Table 2 U.S. Agricultural Exports to USSR, 1980-1984 (dollar values are USD)

\begin{tabular}{cccc}
\hline $\begin{array}{c}\text { Total value of U.S. } \\
\text { agricultural exports to } \\
\text { USSR }\end{array}$ & $\begin{array}{c}\text { Value of U.S. grain } \\
\text { exports to USSR }\end{array}$ & $\begin{array}{c}\text { U.S. grain sales to USSR } \\
\text { (million metric tonnes) }\end{array}$ \\
\hline 1980 & \$1.13 billion & $\$ 1.02$ billion & 6.66 \\
1981 & \$1.68 billion & $\$ 1.57$ billion & 9.65 \\
1982 & \$1.87 billion & $\$ 1.63$ billion & 11.42 \\
1983 & \$1.47 billion & $\$ 1.20$ billion & 7.86 \\
1984 & \$2.87 billion & $\$ 2.62$ billion & 18.26 \\
\hline
\end{tabular}

Source Kathryn A. Zeimetz, USSR Agricultural Trade, Statistical Bulletin 808 (Washington, DC: United States Department of Agriculture, Economic Research Service, 1991), 37, 39

in its first Gulf War against Iraq. ${ }^{39}$ Unfortunately for Gorbachev, the broad-based economic assistance that he had counted on was not forthcoming from the United States, a fact that was deeply disappointing to Soviet leaders. ${ }^{40}$ But the Americans were willing to sell food, and thus agricultural trade reached a single year high point in 1989 at $\$ 3.59$ billion USD. In that year, the USSR purchased over $21 \mathrm{mmt}$ of American wheat and corn.

\section{5 ig9os Foreign Policy Context}

Following the breakup of the Soviet Union in December 1991, the remainder of decade ushered in significant changes in world politics and the U.S.-Russia bilateral relationship. The end of the Soviet Union lowered bilateral political tensions and witnessed multilateral economic cooperation as post-Soviet Russia joined international and regional organisations. It also meant that the U.S.-USSR ideological competition that had dominated world politics during the Cold War faded away. The zerosum game that had defined bilateral relations was replaced by a search for mutual security, although this desire was often frustrated by mistrust and misunderstanding especially with regard to political arrangements in Europe.

Further, the collapse of the Soviet Union diminished military-strategic competition. With the subsequent collapse of the Russian economy and deep cuts in its military spending, Russia was no longer a global threat, at least in conventional weaponry. Competition between the two nations 
was characterised by asymmetrical power in favour of the United States. ${ }^{41}$ One constant in the bilateral relationship was the U.S. as a provider of economic assistance and as the dominant player in the global financial system. In the late Gorbachev period and early post-Soviet period, political leaders in Moscow were hoping for assistance from the U.S. along the lines of the Marshall Plan, but by about 1994 it became clear that that level of assistance would not be forthcoming. ${ }^{42}$

Even without a massive aid package that the Russians had hoped for, the 1990s represented a honeymoon decade in U.S.-Russian relations during which the relationship was warmer and more cooperative than at any other time in the twentieth century. Russian President Boris Yeltsin and U.S. President Bill Clinton were on a first name basis and met no less than eight times during 1993-1999. The core reasons for this new phase in the bilateral relationship were the demise of Marxist-Leninist ideology that viewed international relations as inherently conflictual between capitalist and socialist states, and the rise of a pro-Western vision of national identity and foreign policy. ${ }^{43}$ Russia's post-Soviet leaders saw their country as part of Western civilisation whose identity had been 'hijacked' by the Bolsheviks and the Soviet system. ${ }^{44}$ Tsygankov argues that the new concept of the post-Soviet identity emphasised partnership with the West and was predicated on rapid membership in Western international organisations; radical economic reforms that would usher in a market economy; and isolationism from the former Soviet region. This new foreign policy concept was signed into law in 1993. ${ }^{45}$

During the decade, the two sides signed the START 2 arms control treaty in 1993 and an agreement to ban chemical weapons in 1996; adhered to the Nunn-Lugar programme to help Russia destroy its nuclear weapons; and conducted on-site inspections to enforce the Intermediaterange Nuclear Force treaty. The two sides also cooperated on the construction of democracy, civil society, and human rights in Russia. There were regular meetings between the Russian Foreign Minister and the U.S. Secretary of State; and in 1995 regular meetings convened between Russian Prime Minister Viktor Chernomyrdin and U.S. Vice President Albert Gore. There were also economic achievements: a \$24 billion USD aid package from the U.S. in 1992; an American-led G7 commitment for an aid package of more than $\$ 43$ billion USD; the rescheduling of $\$ 70$ million USD of Soviet debt with the Paris Club; and a U.S.-backed \$10 billion USD aid package from the IMF in 1998. 
In short, the relationship moved from being defined by conflicting and diverging interests to parallel and common interests. ${ }^{46}$

The improvement in bilateral relations did not imply an absence of problems. The December 1993 Duma election witnessed the emergence of powerful nationalist politicians that led to 'a series of tactical concessions that reflected the changing balance of domestic power' away from Westernism. ${ }^{47}$ In an embarrassing moment, Foreign Minister Andrei Kozyrev had asked for a special session of NATO foreign ministers at which he would presumably announce Russia's membership in the Partnership for Peace. Instead, at the December 1994 meeting, Kozyrev indicated that Russia was not yet ready to join. Then-Secretary of State Warren Christopher recalls being 'flabbergasted and embarrassed....Russia was putting a thumb in our eye' ${ }^{48}$ After the meeting, Kozyrev explained to Christopher that hardliners had convinced Yeltsin not to join the Partnership for Peace. Russia finally joined the Partnership for Peace in May 1995. Russian leaders also complained about patronising and condescending treatment by the United States, claims that would seem to be justified given that the Clinton administration expected Russia to adopt Western views of security for Europe. By 1995, pro-Western Foreign Minister Kozyrev was openly asking the West whether it wanted 'Partnership or Cold Peace' between the two countries by way of complaining about U.S. unilateralism in the Balkans. ${ }^{49}$ There were other tensionsU.S. support for an independent Kosovo in 1997, economic aid that Russia felt was insufficient before and after the 1998 financial crisis in Russia, and the U.S. bombing of Serbia in 1999, which was an ally of Russia.

The decision to expand NATO to include former communist satellite nations in Eastern Europe in 1999 was especially contentious. Christopher notes that Russia's opposition to NATO enlargement seemed to centre around a lack of respect from the United States. From Christopher's own descriptions, the U.S. essentially dictated to Russia that NATO would enlarge and bring in former communist nations in Europe ${ }^{50}$ Christopher's successor, Secretary Madeline Albright, also noted that 'part of our strategy, of course, was to convince the Russians that enlargement would go forward with or without their agreement'.51 Robert Gates, who served as Secretary of Defence from 2006 to 2011, observed that during the 1990s, 'we did not take Russian interests seriously. We did a poor job of seeing the world from their point of view, and of managing the relationship for the long term'. ${ }^{52}$ 
Eventually, Albright admits that 'we wore the Russians down'. ${ }^{53}$ Not only did NATO expand, but the NATO-Russia Charter shut Russia out of a formal role in NATO's decision-making process. Yeltsin had little choice but to accept what the Americans decided. ${ }^{54}$ But Russian unhappiness with the way they were treated was reflected in their negotiation strategy which was characterised as similar to a 'dental root canal'. Albright writes that 'Moscow wanted the ordeal [NATO enlargement] to be so painful that we would forget about further rounds' ${ }^{55}$

Despite tensions in the relationship, the U.S. remained fully invested in Boris Yeltsin and supported him through his extra-constitutional actions in September-October 1993 when he disbanded Parliament; the brutal conduct Chechen war of 1994-1996 during which rape, genocide, and murder were common; flagrant violations of a free and fair presidential election in 1996; and Russia's 1998 financial meltdown that effectively ended Russia's experiment with de-statisation. The broader point is that the bilateral relationship was generally positive during the 1990s and cooperation, even if strained at times, replaced military confrontation.

\section{U.S. Agricultural Exports in the ig9os}

Building on a record value of U.S. grain exports to the USSR in 1989 ( $\$ 3.59$ billion USD), in 1990 the United States and the Soviet Union signed a new grain agreement. This agreement raised the Soviet Union's minimum annual purchase to $10 \mathrm{mmt}$ and included barley and sorghum for the first time. The Soviets were given the right to buy up to $14 \mathrm{mmt}$ without advance notification, up from $12 \mathrm{mmt}$. The Soviets also agreed to buy a minimum of $4 \mathrm{mmt}$ of wheat and feed grain. ${ }^{56}$ As a result, 19901991 witnessed continued high levels of U.S. agricultural exports, with more than $\$ 4.5$ billion USD in agricultural exports to the USSR despite its limited hard currency reserves.

With the fall of communism and the emergence of a democratic and market-oriented government in Moscow, it could be expected that the improving bilateral political relationship would build upon the trade momentum of 1988-1991, especially considering the economic difficulties that Russia's transition to a market economy were experiencing. It would be reasonable to expect that warmer political relations would be accompanied by much higher agricultural trade. In fact, however, higher valuations of agricultural exports did not occur, instead of dropping from $\$ 2.45$ billion USD in 1991 to $\$ 1.12$ billion USD in 1992 and never 
exceeding \$1.5 billion USD for the rest of the decade. The volume of the main U.S. export in the past, grain, began to decline precipitously. The improving political relationship after 1992 contrasts with trends in agricultural trade which were lower than 1990-1991 and lower than the 1980-1984 period. Thus, the relationship between politics and agricultural trade was divergent, but not as much as during the 1980-1984 period. Annual U.S. agricultural exports during the 1990s are shown in Table 3.

The table demonstrates three occurrences about U.S. food exports to Russia: (1) the value of U.S. agricultural exports declined after 1992; (2) the value of grain exports comprised a smaller percentage of total agricultural exports as the decade progressed; and (3) the quantity of grain exports declined after 1992.

Mild divergence is further witnessed by lower annual valuations of U.S. agricultural exports than in the last decade of the Soviet period. During 1992-1999, the value of U.S. agricultural exports totaled \$9.01 billion USD, or an annual average of \$1.1 billion USD for the eight-year period. In comparison, during the 1980-1984 period, U.S. agricultural exports

Table 3 U.S. Agricultural Exports to USSR/Russia in 1990s (dollar values are USD)

\begin{tabular}{cccc}
\hline & $\begin{array}{c}\text { Total value of U.S. } \\
\text { agricultural exports to } \\
\text { USSR/Russia }\end{array}$ & $\begin{array}{c}\text { Value of grain exports to } \\
\text { USSR/Russia }\end{array}$ & $\begin{array}{c}\text { Quantity of grain export } \\
\text { to USSR/Russia }\end{array}$ \\
\hline 1990 & $\$ 2.26$ billion & $\$ 1.68$ billion & $13.2 \mathrm{mmt}$ \\
1991 & $\$ 2.45$ billion & $\$ 1.78$ billion & $16.5 \mathrm{mmt}$ \\
1992 & $\$ 1.12$ billion & $\$ 738$ million & $5.9 \mathrm{mmt}$ \\
1993 & $\$ 1.22$ billion & $\$ 682$ million & $6.0 \mathrm{mmt}$ \\
1994 & $\$ 1.00$ billion & $\$ 45$ million & $303.9 \mathrm{tt}$ \\
1995 & $\$ 1.45$ billion & $\$ 80$ million & $444.0 \mathrm{tt}$ \\
1996 & $\$ 1.32$ billion & $\$ 56$ million & $223.2 \mathrm{tt}$ \\
1997 & $\$ 1.20$ billion & $\$ 27$ million & $114.3 \mathrm{tt}$ \\
1998 & $\$ 98.5$ million & $\$ 9$ million & $40.6 \mathrm{tt}$ \\
1999 & $\$ 728.0$ million & $\$ 257$ million & $1.90 \mathrm{mmt}$ \\
\hline
\end{tabular}

Notes (a) Data for agricultural exports in 1990-1991 are for USSR, thereafter they are for Russia (b) $\mathrm{mmt}=$ million metric tonnes (c) $\mathrm{tt}=$ thousand metric tonnes. Sources Kathryn A. Zeimetz, USSR Agricultural Trade, Statistical Bulletin 808 (Washington, DC: United States Department of Agriculture, Economic Research Service, 1991), 37, 39; and Foreign Agricultural Service database at https://apps.fas.usda.gov/GATS/default.aspx 
totaled $\$ 9.02$ billion USD, or an annual average of $\$ 1.8$ billion USD during the five-year period. Further, U.S. grain exports declined from $16.5 \mathrm{mmt}$ in 1991 to about $6 \mathrm{mmt}$ in 1992 and 1993, and thereafter did not come close to 500 thousand tonnes for the rest of the decade. Another perspective on the decline is to note that during 1982-1989, a period generally considered to be one of poor agricultural performance and high grain imports, the average annual domestic grain production was $98.8 \mathrm{mmt}$ per year. During 1992-1999, Russia's annual average domestic grain harvests declined to $76.3 \mathrm{mmt}$ a year. ${ }^{57}$ And yet, Russian grain imports declined after 1992.

The decline in U.S. grain exports to Russia was due to economic changes in demand within Russia. Due to high food inflation and contraction in real per capita income, Russian consumer demand for meat plummeted after 1992 as consumers turned to cheaper starches, carbohydrates, and grains which domestic production could fulfill. ${ }^{58}$ Consumers responded to price changes for food, especially for high-cost livestock products. Farms in turn responded to falling consumer demand and rising prices for fuel, feed, and other inputs by slashing livestock herds. The result was a decline in animal husbandry that rivaled the mass slaughter of the early 1930s when peasants resisted collectivisation. In 1996, for example, the number of cattle was 70 percent and the number of pigs was 59 percent of the 1990 level. The number of cattle and pigs continued to decline, falling to 49 percent and 48 percent of the 1990 level by 2000 , respectively. ${ }^{59}$ As demand for meat plummeted and the number of farm animals decreased, the need (demand) for imported feed grain evaporated.

As Russian consumers shifted their demand to cheaper proteins, Russia quickly became the largest importer of poultry meat in the world. Russia's poultry imports rose from about 46 thousand tonnes in 1992 to 500 thousand tonnes in 1994, and then to 1.14 million tonnes in 1997. In 1997, 70 percent of Russia's poultry imports came from the United States. ${ }^{60}$ U.S. poultry exporters earned in excess of $\$ 1$ billion USD annually from trade with Russia from about mid-decade onward. Chicken meat replaced grain as the main U.S. agricultural export to Russia.

Russia's dependence on foreign meat and poultry impacted Russia's food import policy. ${ }^{61}$ Protectionist policies began to emerge in middecade to protect the domestic food market from imports. Advocates of more protectionism cited Russia's comparative disadvantage in land productivity and harsher climatic conditions that made it difficult to 
compete with lower international prices. ${ }^{62}$ To assist domestic producers to retain market share, food import tariffs were increased in mid-1995. The tariff on meat (non-poultry) increased from 8 to 15 percent; on poultry and sugar from 20 to 25 percent; and on butter from 15 to 20 percent. ${ }^{63}$ In 1996, the Russian government raised import tariffs on alcohol, chicken, and other food products that resulted in an average weighted tariff of 14 percent. ${ }^{64}$ Further, in July 1996 import quotas were introduced for the first time on meat, milk, and poultry products, but withdrawn in December 1996 under U.S. pressure.

In addition, in 1996 the first of several disputes over U.S. chicken exports arose. In February 1996, a controversy arose when the Russian Ministry of Agriculture announced that its veterinary service would deny import certification to many U.S. poultry processing plants, in effect placing a temporary ban of American poultry exports. Critics in the U.S. argued that the sanitary issue was Russia's pretext for what was really a political demonstration of power by Russian conservatives whose influence was rising following the departure of Foreign Minister Andrei Kozyrev and First Vice Premier Yegor Gaidar from Yeltsin's cabinet. The controversy was settled in March 1996 following negotiations that led to Russia accepting the U.S. poultry inspection system. The issuance of import licenses was resumed and chicken imports that had been shipped when the dispute arose were admitted into the country by Russian customs. The 'chicken war' between the U.S. and Russia would extend into the next decade. ${ }^{65}$

America's agricultural exports to Russia encompassed not only commercial sales. U.S. food aid was first extended to the Soviet Union in 1990-1991 when the Bush administration was informed of the possibility of hunger and even starvation. Those forecasts turned out to be exaggerated but nonetheless food aid was continued during the Clinton administration. By 1993-1994 it became clear that U.S. food aid to Russia was suffering from waste, loss, and corruption. The Russian state grain monopoly colluded with a small group of banks and grain auction houses to buy up U.S. supplies of grain at artificially low prices. These supplies undercut existing private farmers and kept domestic grain prices so low that they were a formidable barrier to entry for prospective growers. According to estimates by the United States Department of Agriculture, no more than 5 percent of aid reached intended recipients. ${ }^{66}$ In 1994, the U.S. reoriented its distribution away from state-owned grain distributors to private farmers. During fiscal years 1994-1998, the U.S. 
government underwrote the delivery of millions of tonnes of wheat, corn, and soybeans, as well as tens of thousands of tonnes of rice, barley, and rye to Russia. ${ }^{67}$

As one aid package came to an end, another began in late 1998. Following a very poor harvest in 1998, in November of that year the United States set up a $\$ 1$ billion USD food aid package to avoid mass hunger in the Far East and other remote regions of Russia. The aid package consisted of $1.5 \mathrm{mmt}$ of wheat worth $\$ 600$ million USD as humanitarian assistance, and a $\$ 400$ million USD line of credit to purchase additional food at 2 percent interest repayable over twenty years after a five-year grace period. The U.S. also agreed to pay shipping costs, which totaled more than $\$ 300$ million USD. Food aid began to arrive in Russia in March 1999, although the bulk of aid was not shipped until late summer 1999, and even then few small towns in remote areas where aid was needed actually received food. A large share of the aid remained in Moscow and St. Petersburg. ${ }^{68}$ In January 1999, the U.S. donated additional seed for Russia's spring sowing. ${ }^{69}$

\section{Foreign Policy Context Since 2000}

At the turn of the century, both countries were disappointed in the other. The U.S. was losing hope that Russia would democratise; U.S. leaders were frustrated with the level of corruption in the Russian government; and they were concerned about stalled economic reform following Russia's financial collapse of August 1998. The incoming Bush administration downplayed the geostrategic importance of Russia and instead articulated other priorities. ${ }^{70}$ President Clinton's engagement with Russia in the 1990s gave way to 'Russia fatigue'. The Kremlin was disillusioned as well. Secretary of Defense Donald Rumsfeld recounts how President Vladimir Putin argued that Russia was being 'pushed out' of collective defense with the West for which Putin blamed the West. ${ }^{71}$ Russian political leaders continued to be offended at the lack of respect by the Americans, an issue that Rumsfeld says he explicitly tried to address. ${ }^{72}$ Lingering bitterness over NATO expansion led to early tension between the two countries. The tension escalated when FBI agent Philip Hanssen was arrested and charged with spying for Moscow for 15 years. The Bush administration ordered the expulsion of 50 Russian diplomats from the U.S. in March 2001. ${ }^{73}$ Russia retaliated and expelled U.S. diplomats, behaviour reminiscent of the Cold War. Unlike the Soviet period, 
however, the rivalry between the two countries flowed from big power competition and increasing nationalism in Russia rather than incompatible political ideologies.

The bilateral drift came to an abrupt halt with the 9/11 attacks. Not only was Putin among the first world leaders to offer condolences to President George W. Bush, the aftermath brought concrete cooperation in counterterrorism as the U.S. began military action against the Taliban in Afghanistan. There was also cooperation in nuclear proliferation as Russia joined the West in trying to limit Iran's nuclear capabilities. The reemergence of common interests was able to withstand the announcement of another round of NATO expansion in 2002 that brought in the Baltic states and the announcement of a 'big bang' expansion of the European Union that witnessed almost all former Soviet satellite nations in Eastern Europe join the Western sphere of influence in 2004. Further, after notifying the Russians of intent, in June 2002 the United States withdrew from the ABM Treaty that had existed since 1972, a move denounced by Putin. The U.S. also continued with the development of a modest missile defense system in Europe, which, according to Rumsfeld, Putin said he understood did not threaten Russia's security interests. ${ }^{74}$

By 2003, however, disagreements outweighed cooperation. Putin made clear his opposition to the U.S. invasion of Iraq in March 2003. Later in 2003, the Russian government took over oil giant Yukos in 2003 and subsequently imprisoned its CEO, Mikhail Khodorkovsky, in 2004. ${ }^{75}$ Stent argues that the Yukos affair had a minimal impact on the political relationship. ${ }^{76}$ However, in the financial sphere, foreign direct investment (FDI) into Russia collapsed in the fourth quarter of 2003 and declined from a net of $+\$ 1.79$ billion USD in 2003 to net $-\$ 1.62$ billion USD in 2004, which reflected concerns over the sanctity of private property in Putin's Russia. ${ }^{77}$

Even as Western FDI dried up, the bilateral trade relationship between the United States and Russia began to take off. Total U.S. exports in goods to Russia increased from \$2.4 billion USD in 2003 and eventually reached a high of $\$ 11.1$ billion USD in 2013. Even more impressive was the growth in Russia's exports of goods to the U.S., which increased from $\$ 8.6$ billion USD in 2003 to a high of $\$ 34.6$ billion USD in 2011. Most of Russia's exports to the U.S. were energy-related and in general, there were several cooperative energy projects up to $2008 .^{78}$ The U.S. trade balance in goods since 2000 is presented in Table 4, showing that the 
Table 4 U.S. Trade Balance with Russia (dollar values are USD)

\begin{tabular}{lccc}
\hline & $\begin{array}{c}\text { Total value of } \text { U.S } \\
\text { exports to Russia }\end{array}$ & $\begin{array}{c}\text { Total value of U.S. } \\
\text { imports from Russia }\end{array}$ & Trade balance \\
\hline $\begin{array}{l}\text { 1992-1999 annual } \\
\text { average }\end{array}$ & $\$ 2.85$ billion & $\$ 3.63$ billion & $\$-780$ million \\
2000 & $\$ 2.09$ billion & $\$ 7.65$ billion & $\$-5.56$ billion \\
2001 & $\$ 2.71$ billion & $\$ 6.26$ billion & $\$-3.54$ billion \\
2002 & $\$ 2.39$ billion & $\$ 6.87$ billion & $\$-4.47$ billion \\
2003 & $\$ 2.44$ billion & $\$ 8.61$ billion & $\$-6.17$ billion \\
2004 & $\$ 2.96$ billion & $\$ 11.89$ billion & $\$-8.93$ billion \\
2005 & $\$ 3.96$ billion & $\$ 15.30$ billion & $\$-11.34$ billion \\
2006 & $\$ 4.70$ billion & $\$ 19.82$ billion & $\$-15.12$ billion \\
2007 & $\$ 7.28$ billion & $\$ 19.31$ billion & $\$-12.03$ billion \\
2008 & $\$ 9.33$ billion & $\$ 26.78$ billion & $\$-17.44$ billion \\
2009 & $\$ 5.33$ billion & $\$ 18.19$ billion & $\$-12.86$ billion \\
2010 & $\$ 5.99$ billion & $\$ 25.69$ billion & $\$-19.69$ billion \\
2011 & $\$ 8.31$ billion & $\$ 34.61$ billion & $\$-26.30$ billion \\
2012 & $\$ 10.69$ billion & $\$ 29.36$ billion & $\$-18.66$ billion \\
2013 & $\$ 11.14$ billion & $\$ 27.08$ billion & $\$-15.94$ billion \\
2014 & $\$ 10.75$ billion & $\$ 23.65$ billion & $\$-12.90$ billion \\
2015 & $\$ 7.98$ billion & $\$ 16.37$ billion & $\$-9.28$ billion \\
2016 & $\$ 5.83$ billion & $\$ 14.54$ billion & $\$-8.71$ billion \\
2017 & $\$ 7.00$ billion & $\$ 17.05$ billion & $\$-10.05$ billion \\
2018 & $\$ 6.65$ billion & $\$ 20.87$ billion & $\$-14.21$ billion \\
2019 & $\$ 5.78$ billion & $\$ 22.28$ billion & $\$-16.49$ billion \\
& & &
\end{tabular}

Sources https://www.census.gov/foreign-trade/balance/c4621.html; and Author's calculations

U.S. began to run a chronic trade deficit with Russia after having trade surpluses through 1994.

Even as bilateral trade ramped up, the political relationship drifted. Following the tragic loss of life in the 2004 Beslan school murders, Putin seemed to implicate the United States for the event in a speech to the Russian people. ${ }^{79}$ In the wake of Beslan, Putin imposed stricter control over domestic politics by changing the election system for the State Duma in a way that benefited the pro-Kremlin party United Russia; he ended gubernatorial elections; banned electoral blocs in the Duma; revised the way members of the Federation Council were selected; and replaced elected city mayors with appointed city managers in many regions. The cumulative political effect was a significant backsliding from democracy and the rise of human rights abuses that caused concern in Washington. ${ }^{80}$ 
The next few years deepened the political mistrust between the two countries. In 2006, Russia felt mislead in its quest to join the World Trade Organisation (WTO), accusing the United States of double standards that held up Russia's membership. ${ }^{81}$ In a February 2007 speech at a security conference in Munich, Putin recited a long list of complaints about the American-dominated unipolar world. He excoriated the United States for provoking a new nuclear arms race, undermining international institutions, destabilising the Middle East by invading Iraq, and increasing tensions through the expansion of NATO, which he said, can only be interpreted as directed at Russia. ${ }^{82}$ Secretary of Defence Robert Gates, who was in attendance at the Munich security conference, was stunned by Putin's 'harshness' but decided to respond in a humourous manner, observing that 'by the nods and smiles throughout the hall, I knew I had taken the right tack' ${ }^{83}$

In 2008, during Russia's abbreviated war with Georgia, Foreign Minister Sergei Lavrov tried to enlist the support of the United States to remove Georgian President Saaskashvili whom the Russians considered an annoyance. Washington, of course, refused. In the aftermath of the war, Russia withdrew from the NATO-Russia Council, followed by NATO's declaration of support for Georgia and its territorial integrity and independence. NATO called on Russia to withdraw its troops. Immediately after the war ended, the U.S. signed a missile defence pact with Poland, the timing of which former Secretary of State Condoleeza Rice claims was coincidental but even if that claim is true, the Russians perceived it as ratcheting up tensions in Europe. ${ }^{84}$ Robert Gates, who was Secretary of Defence during the Georgian war, gives the impression that the missile defence pact with Poland was a response to Russian aggression in Georgia. Further, he indicated that Russian behaviour 'called into question the entire premise of our dialogue'. He continued that, 'all of the nations of Europe are looking at Russia through a different set of lenses'. ${ }^{85}$ In the aftermath of the Georgian war, the U.S. tabled Russia's application to the WTO to show its opposition to Russia's unilateral redefinition of borders of Georgia. ${ }^{86}$ Russia's entry into the WTO would not be reconsidered until the Obama administration, which led to eventual membership in 2012.

The 2009 'reset' in bilateral relations and subsequent 2010 START arms control agreement were exceptions to the downward trend in relations. During the 'reset', the two countries experienced some cooperative successes-sanctions against Iran and North Korea, opening a northern 
supply route to Afghanistan, getting a UN resolution on a no-fly zone in Libya passed, and Russia's membership in the World Trade Organization. Yet, once Putin retook the presidency in 2012, relations cooled. Putin declined President Obama's invitation to the G8 meeting at Camp David in May 2012; Russia adopted an uncooperative stance with regard to Syria by backing the Assad regime; and Putin cracked down on internal dissent and protest (for which he blamed former Secretary of State Hillary Clinton for instigating). Clinton writes that 'for those who expected the reset to open a new era of goodwill between Russia and the United States, it proved to be a bitter disappointment'. ${ }^{87}$ Perhaps the failure of the reset was inevitable. Stent argues that 'U.S.-Russian relations were indeed overburdened by a legacy of disagreements and mutual mistrust from both the Cold War and post-Cold-War periods' ${ }^{88}$ From Russia's perspective, contested issues such as U.S. missile defence, U.S. meddling in Russia's domestic affairs, European security, and U.S. behaviour in the Middle East continued to affect relations negatively. In December 2012, the socalled 'Magnitsky Act' passed in the U.S. Senate 92-4, denying visas and freezing the assets of Russian nationals who U.S. officials believed were complicit in the murder of Sergei Magnitsky, the former accountant from Hermitage Capital who died in a Russian prison in 2009 after weeks of torture and abuse. ${ }^{89}$ Putin was furious over the Magnitsky Act and tried to prevent its passage, but when he could not, Russia retaliated by adopting the Dima Yakovlev Law two weeks later, which permanently banned the adoption of Russian children by U.S. parents.

Heightened tensions surrounding the Ukraine crisis of late 2013-early 2014 were symptoms rather than causes for a relationship that would fall to new lows after summer 2014 and continued into 2020. The 2014 political crises in Ukraine - the Yanukovych presidency, the annexation of Crimea, and independence movements in Ukraine's eastern provincespoisoned the relationship and created a trap of acrimony that neither side seems willing or able to end. In March 2014, following Russia's annexation of Crimea, Putin threw down the gauntlet when he accused the West of 'primitive, blunt cynicism'. He alleged that the West has 'lied to us many times, made decisions behind our backs, [and] placed before us an accomplished fact', referring specifically to the expansion of NATO and missile defence. He continued that 'they are constantly trying to sweep us into a corner because we have an independent position, because we maintain it and because we call things like they are and do not engage in hypocrisy. But there is a limit to everything, .00 
The breadth and depth of animosity led journalists and some academics to speak of a 'New Cold War'. ${ }^{91}$ To be sure, there were differences with the original Cold War, for instance the lack of ideological competition, different Russian motivations, and certainly a change in Russia's capabilities. $^{92}$ Nonetheless, heightened tensions after 2014 were unparalleled in the post-Soviet period. Intensified rivalry, competition, and 'hybrid warfare' replaced cooperation. A representative but not exhaustive summary includes the following. The United States feared a potential Russian attack on the Baltics or even worse, a 'frozen conflict' in countries with a high percentage of ethnic Russians. Russia opposed a modest increase in NATO troops in Poland and Lithuania while engaging in actions that motivated that increase. The U.S. contested Russia's military support for Syrian President Bashar al-Assad starting in 2015, which came without any advance notification to the U.S., and which former Secretary of State John Kerry characterised as eviscerating U.S. leverage in Syria and setting the stage for even more blood-letting. ${ }^{93}$ Despite opposing Russian troops in Syria, the U.S. took no direct action against Russian forces in Syria. The U.S. criticised Russia's closer relations with Iran. ${ }^{94}$ Russian energy supplies to Europe became a contentious policy issue and the U.S. pressed its European allies to diversify their sources in order to lower dependence on Russia. In March 2018, the U.S. expelled 60 Russian diplomats over the allegation that the Russian government was behind the nerve agent attack against former military intelligence officer Sergei Skripal and his daughter in England. Putin retaliated by expelling 60 U.S. diplomats and closing the U.S. consulate in St. Petersburg. The U.S. withdrew from the Joint Comprehensive Plan of Action in May 2018. In October 2018, the U.S. informed Russia of its intention to leave the Intermediate Range Nuclear Force Treaty (INF) which had been in effect since 1987. According to former National Security Advisor John Bolton, the Russians used the announcement to play on Europeans' fears that the U.S. was abandoning them, a notion that Bolton dismisses. ${ }^{95}$ Following the U.S. withdrawal from the INF Treaty in August 2019, Putin announced a new hypersonic weapon that could defeat missile defence. Allegations of Russian meddling in the U.S. 2016 presidential election coloured the relationship during the entirety of Trump's presidency. Thus, the political relationship since early 2014 was characterised by nearly unending disagreement and mistrust. 


\section{U.S. Agricultural Exports to Russia Since 2000}

In the post-Soviet period, U.S. agricultural exports to Russia shifted away from grain. As previously noted, Russia imported large quantities of poultry meat from the U.S. in the 1990s. After 1999, poultry and other meat imports continued to increase rapidly as the economy began to grow again and consumers began to realise real gains in their standard of living and income. By 2002, Russia imported double the level of meat compared to 2000 , and meat imports as a percentage of total supply increased from 12 percent in 2000 to 24 percent in $2002 .{ }^{96}$ The dollar value of Russia's food imports would continue to increase for another decade, although not linearly due to the financial crisis of 2008-2009.

Against this context, the story of U.S. agricultural exports to Russia since 2000 is one of decline compared to the 1990s, a brief and modest increase during 2007-2012, and then renewed decline to the point of irrelevance after 2014. U.S. agricultural exports declined for three reasons: (1) the recovery in Russia's agricultural sector, which was able to meet more of domestic demand; (2) an expansion in Russia's other trading partners; and (3) a significant deterioration in the political relationship revolving around the crisis in Ukraine in 2014 that continues to the present. U.S. agricultural exports to Russia during 2000-2019 are presented in Table 5 .

For analytical purposes, U.S. agricultural trade with Russia since 2000 may be separated into three periods. In the first period, 2000-2006, the value of U.S. agricultural exports did not exceed \$1 billion USD, despite the fact that political tensions were between Washington and Kremlin were generally low. ${ }^{97}$ For context, during this period the total value of Russia's agricultural imports increased from \$7.3 billion USD in 2000 to $\$ 21.5$ billion USD in 2006, a rise that reflects higher consumer demand within Russia. The European Union in particular became a major trading partner. Russia was a main export market for agricultural products from the EU. In 2013, the EU exported $€ 10.9$ billion of agricultural goods to Russia, equal to more than 10 percent of its total agricultural exports. By 2016, however, EU food exports to Russia declined to $€ 5.4$ billion before rebounding to $€ 7$ billion in 2019 , equal to about 3.9 percent of non-EU food exports. ${ }^{98}$

In contrast, U.S. agricultural exports to Russia became progressively less important and by 2006 accounted for less than 5 percent of the 
Table 5 U.S. Agricultural Exports to Russia After 2000 (dollar values are USD)

\begin{tabular}{|c|c|c|c|}
\hline $\begin{array}{c}\text { Total value of U.S. } \\
\text { agricultural } \\
\text { exports to Russia }\end{array}$ & $\begin{array}{l}\text { Value of grain } \\
\text { exports to Russia }\end{array}$ & $\begin{array}{l}\text { Quantity of grain } \\
\text { exports to Russia }\end{array}$ & $\begin{array}{l}\text { Percent of U.S. } \\
\text { agricultural } \\
\text { exports to Russia } \\
\text { comprised of } \\
\text { foodstuffs (\%) }\end{array}$ \\
\hline
\end{tabular}

\begin{tabular}{|c|c|c|c|c|}
\hline 2000 & $\$ 580$ million & $\$ 116$ million & $779.5 \mathrm{tt}$ & 68 \\
\hline 2001 & $\$ 917$ million & $\$ 65$ million & $133.9 \mathrm{tt}$ & 87 \\
\hline 2002 & $\$ 552$ million & $\$ 21$ million & $53.9 \mathrm{tt}$ & 88 \\
\hline 2003 & $\$ 579$ million & $\$ 11$ million & $13.4 \mathrm{tt}$ & 87 \\
\hline 2004 & $\$ 802$ million & $\$ 84$ million & $90.1 \mathrm{tt}$ & 83 \\
\hline 2005 & $\$ 972$ million & $\$ 72$ million & $25.2 \mathrm{tt}$ & 87 \\
\hline 2006 & $\$ 820$ million & $\$ 53$ million & $43.6 \mathrm{tt}$ & 87 \\
\hline 2007 & $\$ 1.32$ billion & $\$ 86$ million & $60.2 \mathrm{tt}$ & 88 \\
\hline 2008 & $\$ 1.83$ billion & $\$ 92$ million & $35.1 \mathrm{tt}$ & 90 \\
\hline 2009 & $\$ 1.42$ billion & $\$ 90$ million & $116.7 \mathrm{tt}$ & 88 \\
\hline 2010 & $\$ 1.13$ billion & $\$ 67$ million & $65.6 \mathrm{tt}$ & 86 \\
\hline 2011 & $\$ 1.24$ billion & $\$ 71$ million & $69.1 \mathrm{tt}$ & 79 \\
\hline 2012 & $\$ 1.65$ billion & $\$ 99$ million & $102.2 \mathrm{tt}$ & 71 \\
\hline 2013 & $\$ 1.20$ billion & $\$ 230$ million & $309.0 \mathrm{tt}$ & 60 \\
\hline 2014 & $\$ 900$ million & $\$ 246$ million & $362.0 \mathrm{tt}$ & 56 \\
\hline 2015 & $\$ 426$ million & $\$ 236$ million & $524.8 \mathrm{tt}$ & 23 \\
\hline 2016 & $\$ 250$ million & $\$ 95$ million & $164.7 \mathrm{tt}$ & 36 \\
\hline 2017 & $\$ 193$ million & $\$ 24$ million & $6.6 \mathrm{tt}$ & 47 \\
\hline 2018 & $\$ 233$ million & $\$ 17$ million & $5.1 \mathrm{tt}$ & 39 \\
\hline 2019 & \$191 million & $\$ 17$ million & $4.7 \mathrm{tt}$ & 23 \\
\hline
\end{tabular}

Notes (a) Total value of U.S. agricultural exports includes foodstuffs, intermediate products, and bulk goods. In this table, grain exports are defined as bulk goods. The value of U.S. exports excludes agricultural-related products which are non-food products as defined by the USDA. See Table 6 for full definitions. (b) Numbers have been rounded. (c) Data for agricultural exports in 1990-1991 are for USSR, thereafter they are for Russia. (d) $\mathrm{tt}=$ thousand metric tonnes. Sources Kathryn A. Zeimetz, USSR Agricultural Trade, Statistical Bulletin 808 (Washington, DC: United States Department of Agriculture, Economic Research Service, 1991), 37, 39; Foreign Agricultural Service database at https://apps.fas.usda.gov/GATS/default.aspx; and Author's calculations

value of Russia's food imports. The relatively low level of U.S. agricultural exports to Russia marked a departure from the 1990s when all but two years surpassed \$1 billion USD and those two years, 1998-1999, were due to financial crisis and the devaluation of the ruble that made imports more expensive. Thus, the value of U.S. agricultural exports to Russia during 2000-2006 was lower than in the 1980s and 1990s and comprised an insignificant percentage of Russia's total food imports. 
Table 6 Distribution of U.S. Agricultural Exports to Russia 2014-2019 (dollar values are USD)

\begin{tabular}{ccccc}
\hline & $\begin{array}{c}\text { Total value of U.S. } \\
\text { agricultural exports to } \\
\text { Russia }\end{array}$ & $\begin{array}{c}\text { Intermediate } \\
\text { products }\end{array}$ & $\begin{array}{c}\text { Consumer oriented } \\
\text { products }\end{array}$ & Bulk products \\
\hline 2014 & $\$ 900$ million & \$151 million & $\$ 502$ million & $\$ 245$ million \\
2015 & $\$ 4269$ million & $\$ 90$ million & $\$ 99$ million & $\$ 236$ million \\
2016 & $\$ 250$ million & $\$ 64$ million & $\$ 90$ million & $\$ 95$ million \\
2017 & $\$ 193$ million & $\$ 77$ million & $\$ 90$ million & \$24 million \\
2018 & $\$ 233$ million & $\$ 123$ million & $\$ 91$ million & $\$ 17$ million \\
2019 & $\$ 191$ million & $\$ 90$ million & $\$ 83$ million & $\$ 17$ million \\
\hline
\end{tabular}

Notes (a) Numbers have been rounded. (b) Intermediate goods include: soybean oil, soybean meal, vegetable oil, animal fat, live animals, hides and skins, hay, distiller grain, planting seeds, sugars and sweeteners, and other intermediate goods. (c) Consumer oriented goods are essentially foodstuffs and include: beef and beef products, pork and pork products, poultry and poultry products, eggs and egg products, dairy products, fresh fruit, fresh vegetables, processed vegetables, fruit and vegetable juices, tree nuts, chocolate and cocoa products, snack foods, breakfast cereals, condiments and sauces, prepared foods, wine and beer, non-alcoholic beverages, dog and cat food, and other consumeroriented products. (d) Bulk goods are crop products and include: wheat, corn, coarse grains, rice, soybeans, cotton, pulses, tobacco, and other bulk commodities. (e) Agricultural-related goods are excluded from the total value of agricultural exports. They are defined as: distilled spirits, ethanol, biodiesel, forest products, and fish products. All definitions are taken from United Stated Department of Agriculture. Source Foreign Agricultural Service database at https://apps.fas.usda.gov/GATS/def ault.aspx

During the 2000-2006 period, the value of U.S. grain exports comprised a small percentage of the overall value of bilateral agricultural trade. The volume of U.S. grain exports to Russia did not exceed 100 thousand tonnes during 2002-2006. That said, agricultural exports from the U.S. during the 2000-2006 period were overwhelming 'consumeroriented products', a term used by the U.S. Department of Agriculture that basically refers to foodstuffs. In 2000, foodstuffs comprised 68 percent of the dollar value of U.S. agricultural exports to Russia; thereafter and through 2006, the percentage did not drop below 83 percent and most years was $87-88$ percent. In short, the overwhelming majority of U.S. agricultural exports to Russia consisted of food.

From the Russian side, the 2000-2006 period brought stabilisation and then rebound in agricultural production. The period also served to lay a legislative and policy foundation for future growth, guided by a strategic plan that led to the creation of a state-owned agricultural bank through which credits and subsidies could be channeled; financial debt relief for 
large farms; the creation of a mechanism for state intervention in the grain market; the introduction of a new credit policy; and in 2005 the development of a 'national project' that channeled unprecedented levels of financial assistance, credit, and subsidies to agriculture during 20062007. ${ }^{99}$ The strategy of 'bringing the state back in' paid off, as growth in agricultural production on large farms averaged more than 4 percent per annum during 2000-2006. ${ }^{100}$

During the second period, 2007-2013, the political relationship had its ups and downs while U.S. agricultural exports to Russia increased modestly from $\$ 832$ million USD in 2006 to $\$ 1.32$ billion USD in 2007. Exports stayed above the $\$ 1$ billion USD threshold through 2013, though never exceeding $\$ 1.65$ billion USD. The political relationship was framed by Putin's February 2007 speech in Munich; the 2008 Georgian war; a largely inconsequential 'reset' in 2009; the START arms control agreement in 2010; and U.S. support for Russia's entry into the WTO in 2011 with membership finalised in 2012. Because the political relationship had aspects of cooperation and competition during 20072013, I characterise the relationship between politics and agricultural trade as neither convergent nor divergent. During the 2007-2013 period, foodstuffs remained the dominant U.S. agricultural export to Russia, but their percentage declined over time. During 2007-2009, foodstuffs accounted for 88-90 percent of U.S. agricultural exports to Russia, but this percentage declined to 71 percent in 2012 and to 60 percent in 2013 even as the level of agricultural imports from the U.S. remained above \$1 billion USD.

The third period, 2014-present, has witnessed a significant decrease in U.S. agricultural exports to Russia brought about by Russia's countersanctions that ban the importation of most agricultural products from the United States and other Western nations. The decline in the value of U.S. agricultural exports is convergent with the deterioration in political relations. Prior to Russia's food embargo in August 2014, U.S. agricultural exports were on track to surpass the \$1 billion USD threshold, but the food embargo brought immediate curtailment. After 2014, U.S. agricultural exports continued to decline, eventually falling to just \$191 million USD in 2019. Grain had historically accounted for a large percentage of U.S. exports to Russia, although we saw that situation began to change in the 1990s and continued into the 2000s. Starting in 2003, U.S. wheat exports to Russia fell to zero and remained at zero through 2018 but rose to 433 thousand tonnes in 2019 , still a small quantity. Soy was the 
dominant grain export to Russia during 2014-2016, but soy exports to Russia fell to zero in 2017-2019.

Russia's food embargo brought about a significant redistribution in U.S. agricultural exports away from foodstuffs and towards intermediate goods that are used in processing. The transition is shown in Table 6.

The table depicts the effects of Russia's countersanctions which led to an 80 percent decline in the value of agricultural imports from the United States. Within the overall decline in the value of agricultural exports, the table also shows that from 2014 through 2019 exports of foodstuffs fell from 55 percent of U.S. agricultural exports to Russia in 2014 to 43 percent in 2019; bulk goods, or crop products, also declined, from 27 percent in 2014 to 9 percent in 2019; while intermediate goods increased from 17 percent in 2014 to 47 percent in 2019. Assorted agriculturalrelated goods (products that are not directly consumable) are excluded from the table because this category generally is not very significant in volume or value. For example, agricultural-related goods fell from 6 percent of the dollar value of U.S. exports to Russia in 2014 to 2.5 percent in 2019.

\section{OUTLOOK}

This chapter documented how U.S. agricultural exports to Russia have changed from being a significant factor in the USSR's food security to being essentially irrelevant to food security in the contemporary period. This contemporary irrelevance is measured by a low dollar valuation of U.S. agricultural exports to Russia and the transition away from foodstuffs as the dominant agricultural export.

The historical trading patterns during the Cold War demonstrate that agricultural trade is not dependent on good political relations. However, the difference between now and then is that now Russia has a strong agricultural sector that provides food self-sufficiency in many basic commodities, including grain. For this reason, the outlook for U.S.Russian agricultural trade appears reasonably clear. Russia's 2014 food embargo, which continues through the end of 2022, has rendered U.S. agricultural exports insignificant to Russia. Given the commitment by the Putin regime to food security, food self-sufficiency, and the expansion of its own export capacity, it is difficult to foresee how U.S. exporters can re-gain any significant market share in Russia's food market in the near to medium term, and that is significant because Russia is the largest 
consumer market in Europe. Putin himself noted that once markets are lost, they are hard to recapture. Thus, the contemporary story of U.S.Russia agricultural trade represents the loss of the 'food weapon' as leverage by the exporter and the rise of the power of the importer.

\section{Notes}

1. In this chapter, I use the terms 'agricultural trade' and 'food trade' synonymously although I acknowledge that not all agricultural exports are edible. Moreover, the terms 'agricultural trade' and 'food trade' refer to U.S. exports to the Soviet Union/Russia unless otherwise stipulated; food imports by the U.S. from Russia are minuscule and not discussed.

2. Robert L. Paarlberg, Food Trade and Foreign Policy: India, the Soviet Union, and the United States (Ithaca: Cornell University Press, 1985), 15 .

3. Ibid.

4. Joanne Gowa, Allies, Adversaries, and International Trade (Princeton: Princeton University Press, 1994), 120-121.

5. John Gaddis, 'The Evolution of U.S. Policy Goals Toward the USSR in the Postwar Era', in Gorbachev's Russia and American Foreign Policy, eds. Seweryn Bialer and Michael Mandelbaum (Boulder: Westview Press, 1988), 305-313.

6. Paarlberg, Food Trade and Foreign Policy, chaps, 4, 5, 6 .

7. Barry Riley, The Political History of American Food Aid: An Uneasy Benevolence (Oxford: Oxford University Press, 2017), 173-177.

8. Ibid., 220.

9. Paige Bryan, 'The Soviet Grain Embargo', The Heritage Foundation Backgrounder no. 130 (12 January 1981), 3.

10. Directorate of Intelligence, CIA, 'USSR: The Food Supply Situation', Report SOV 85-10,042, March 1985. Approved for release on 5 February 2010. https://www.cia.gov/library/readingroom/docs/CIARDP86T00591R000100140005-4.pdf. Accessed 1 February 2020.

11. Nicolai N. Petro and Alvin Z. Rubinstein, Russian Foreign Policy: From Empire to Nation-State (New York: Longman, 1997), chaps. 7, 9, 10 11.

12. See Raymond L. Garthoff, Détente and Confrontation: American-Soviet Relations From Nixon to Reagan (Washington, DC: The Brookings Institution, 1985), 842-848.

13. Ibid., 1010.

14. Coit D. Blacker, 'Military Forces', in After Brezhnev: Sources of Soviet Conduct in the 1980s, ed. Robert F. Byrnes (Bloomington: Indiana University Press, 1983), 130. 
15. Garthoff, Détente and Confrontation, 1111.

16. Paarlberg, Food Trade and Foreign Policy; VanGrasstek, Trade and American Leadership, 282-308; and Jeffrey M. Pilcher, Food in World History, $2^{\text {nd }}$ edn. (New York and London: Routledge Publishers, 2017), 80-89.

17. Author's calculations based on data in Robert L. Paarlberg, 'Food as an Instrument of Foreign Policy', Proceedings of the Academy of Political Science, 34, no. 3 (1982): 27. In 1980 the U.S. accounted for 42 percent of international wheat exports and 65 percent of coarse grain exports.

18. Paarlberg, 'Food as an Instrument of Foreign Policy', 27.

19. Ibid., 29.

20. Henry Kissinger, White House Years (Boston: Little, Brown and Co., 1979), 1269-1273.

21. Philip Shabecoff, 'Moscow Agrees to Buy U.S. Grain for $\$ 750$ Million', The New York Times, 9 July 1972. https://www.nytimes.com/1972/ $07 / 09 /$ archives /moscow-agrees-to-buy-us-grain-for-750million-creditsplanned.html. Accessed 5 March 2020.

22. Mark J. Penn, 'America Gets the Shaft', The Harvard Crimson, 16 November 1973. https://www.thecrimson.com/article/1973/11/16/ america-gets-the-shaft-pthe-1972/. Accessed 5 March 2020.

23. James Trager, The Great Grain Robbery (New York: Ballantine Books, 1975).

24. Garthoff, Détente and Confrontation, 456.

25. Robert L. Paarlberg, 'The Soviet burden on the world food system: Challenge and response', Food Policy 1, no. 5 (1976): 398.

26. Clyde H. Farnsworth, 'U.S.-Soviet Grain Deal Nearly Failed', The New York Times, 25 October 1975. https://www.nytimes.com/1975/ 10/25/archives/ussoviet-grain-deal-nearly-failed-mood-is-tense-during27day.html. Accessed 6 April 2020.

27. Josef C. Brada, 'The Soviet-American Grain Agreement and the National Interest', American Journal of Agricultural Economics 65, no. 4 (November 1983): 652.

28. Richard K. Abrams and C. Edward Harshbarger, 'U.S. Agricultural Trade in the 1970s: Progress and Problems', The Economic Review (May 1979). https://www.kansascityfed.org/ /media/files/ publicat/econrev/econrevarchive/1979/2q79abra.pdf. Accessed March $13,2020$.

29. Lester R. Brown, 'The U.S.-Soviet Food Connection', Challenge 25, no. 6 (January-February 1983): 47.

30. Joseph Hajda, The Outlook for East-West Agricultural Trade', in EastWest Relations: Prospects for the 1980s, ed. Giuseppe Schiavone (New York: St. Martin's Press, 1982), 49.

31. Robert L. Paarlberg, 'Lessons of The Grain Embargo', Foreign Affairs 59, no. 1 (Fall 1980): 144. That said, American policymakers faced 
several constraints when using food as a weapon in the 1980s. First, the federal government did not control the entire supply chain for grain exports. There was no central marketing board in U.S. and grain exporters are private companies. Thus, the federal government did not have complete control over grain exports. Second, the International Longshoreman's Association (ILA) influenced grain export policy. During the 1980 grain embargo against the USSR, for example, the ILA refused to load grain that was bound for the Soviet Union. Third, domestic political forces influenced food export policy. In 1975, for example, representatives from farm states prevented President Ford from maintaining the grain embargo against the USSR.

32. VanGrasstek, Trade and American Leadership, 254.

33. See James L. Lindsay, 'Trade Sanctions as Policy Instruments: A Reexamination', International Studies Quarterly 30, no. 2 (June 1986): 155-156.

34. Paarlberg, 'Lessons of The Grain Embargo', 155.

35. Ibid., 150.

36. Ibid., 156.

37. Rosstat, Sel'skoe khoziaistvo, okhota, $i$ okbtnich'e khoziaistvo, lesovodstvo $v$ Rossii 2015 (Moscow: Rosstat, 2015), 92.

38. Steven R. Weisman, 'Reagan Ends Curbs on Export of Grain to Soviet Union', The New York Times, 25 April 1981. https://www.nytimes. com/1981/04/25/world/reagan-ends-curbs-on-export-of-grain-tothe-soviet-union-office.html. Accessed 18 March 2020.

39. Michael R. Beschloss and Strobe Talbott, At the Highest Levels: The Inside Story of the End of the Cold War (Boston: Little, Brown and Co. 1993), 69-125.

40. Anatoly Dobrynin, In Confidence (New York: Times Books, 1995), 632636.

41. Andrei P. Tsygankov, Russia and America: The Asymmetric Rivalry (Cambridge: Polity Press, 2019), 9-10, 284-295.

42. Peter Shearman, 'Russian Foreign Policy Toward the United States', in Russian Foreign Policy Since 1990, ed. Peter Shearman (Boulder: Westview Press, 1995), 116.

43. See Andrei P. Tsygankov, Russia's Foreign Policy: Change and Continuity in National Identity, $4^{\text {th }}$ edn. (Lanham: Rowman and Littlefield, 2016), 59-96.

44. Ibid., 61 .

45. Ibid., 62-64.

46. See Sergey M. Rogov, 'The Changing Perspective of Russian-American Relations', in From Rivalry to Cooperation: Russian and American Perspectives on the Post-Cold War Era, eds. Manus I. Midlarsky, John 
A. Vasquesz, and Peter V. Gladkov (New York: HarperCollins, 1994), $116-25$.

47. Tsygankov, Russia's Foreign Policy, 81.

48. Warren Christopher, Chances of a Lifetime: A Memoir (New York: Scribner, 2001), 281.

49. Andrei Kozyrev, 'Partnership of Cold Peace?' Foreign Policy no. 99 (Summer 1995): 3-14.

50. Christopher, Chances of a Lifetime, 281-288.

51. Madeline Albright, Madam Secretary: A Memoir (New York: Harper Perennial, 2003), 256.

52. Robert M. Gates, Duty: Memoirs of a Secretary at War (New York: Vintage Books, 2014), 158.

53. Albright, Madam Secretary, 259.

54. Christopher, Chances of a Lifetime, 288.

55. Albright, Madam Secretary, 258.

56. Robert D. Hershey, 'U.S.-Soviet Grain Pact is Reached', The New York Times, 23 March 1990. https://www.nytimes.com/1990/03/23/bus iness/us-soviet-grain-pact-is-reached.html. Accessed 6 April 2020.

57. Author's calculations from data in Rosstat, Sel'skoe khoziaistvo, okhota $i$ okhotnich'e khoziaistva, lesovodstvo v Rossii 2015, 80.

58. William Liefert, 'Food Security in Russia: Economic Growth and Rising Incomes are Reducing Insecurity', in Food Security Assessment, GFA-15, Economic Research Service, United States Department of Agriculture (Washington, DC: USDA, 2004), 37.

59. Author's calculations from data in Goskomstat, Regiony Rossii, vol. 2 (Moscow: Goskomstat 2001), 508, 510.

60. V. V. Doikov, 'Rynok miasa i miasoproduktov', Ekonomika sel'skokhoziaistvennykh $i$ pererabatypaiushchikh predpriatii no. 7 (July 1999): 7.

61. See Stephen K. Wegren, 'The Russian Food Problem: Domestic and Foreign Consequences', Problems of Post-Communism 47, no. 1 (2000): $44-45$.

62. See V. Brichko, 'APK i vneshniaia torgovlia', Ekonomist no. 3 (March 1997): 89.

63. Iurii Savin, 'Shag vynuzhdennyi, no neobkhodimyi', Sel'skaia zhizn', 3 June 1995, 2.

64. Stephen K. Wegren with Alexander Nikulin and Irina Trotsuk, Russia's Food Revolution: The Transformation of the Food System (London and New York: Routledge Publishers, 2021), 48.

65. Stephen K. Wegren, Russia's Food Policies and Globalization (Lanham: Lexington Books, 2005), 141-144.

66. See Mark Kramer, 'Food Aid to Russia: The Fallacies of US Policy', Ponars Policy Memo 86, October 1999, 3. http://www.ponarseurasia. org/sites/default/files/policy-memos-pdf/pm_0086.pdf, accessed 12 April 2020. 
67. Ibid.

68. Ibid., 4.

69. Stephen K. Wegren, Alexander Nikulin, and Irina Trotsuk, Food Policy and Food Security: Putting Food on the Russian Table (Lanham: Lexington Books, 2018), 144.

70. Condoleeza Rice, No Higher Honor: A Memoir of My Years in Washington (New York: Crown Publishers, 2011), 23-37; and see also Condoleezza Rice, 'Campaign 2000: Promoting the National Interest', Foreign Affairs, 79, no. 1 (JanuaryFebruary 2000). https://www.foreignaffairs.com/articles/2000-01-01/ campaign-2000-promoting-national-interest. Accessed 3 April 2020.

71. Donald Rumsfeld, Known and Unknown: A Memoir (New York: Penguin Group, 2011), 309.

72. Ibid., 307.

73. James Risen and Jane Perez, "Russian Diplomats Ordered Expelled in a Countermove," The New York Times, 22 March 2001. https://www. nytimes.com/2001/03/22/world/russian-diplomats-ordered-expelledin-a-countermove.html. Accessed 18 June 2020.

74. Rumsfeld, Known and Unknown, 309.

75. For background, see Leon Aron, 'The Yukos Affair', American Enterprise Report, 1 October 2003. https://www.aei.org/research-products / report/the-yukos-affair/. Accessed 15 April 2020.

76. Angela E. Stent, The Limits of Partnership: U.S.-Russian Relations in the Twenty-first Century (Princeton: Princeton University Press, 2014), 202.

77. The World Bank, 'Foreign direct investment, net (BoP, current US\$) Russian Federation', n.d. https://data.worldbank.org/indicator/BN. KLT.DINV.CD?locations=RU\&view=chart. Accessed 15 April 2020.

78. Stent, The Limits of Partnership, 203-210.

79. Task Force for Council on Foreign Relations, Russia's Wrong Direction: What the United States Can and Should Do, Report no. 57 (New York: Council on Foreign Relation, 2006), 27.

80. Committee on International Relations, U.S. House of Representatives, and Committee on Foreign Relations, U.S. Senate, Country Reports on Human Rights Practices for 2005, vol. 1, 109th Congress, 2nd Session (Washington, DC: Government Printing Office, 2006), 1509-1554.

81. Stephen K. Wegren, 'Russian Agriculture and the WTO', Problems of Post-Communism 54, no. 4 (2007): 46-59.

82. See 'Speech and Following Discussion at the Munich Conference on Security Policy', February 10, 2007. http://en.kremlin.ru/ events/president/transcripts/24034. Accessed April 18, 2020. The speech is summarized in Thom Shanker and Mark Landler, 'Putin Says U.S. Is Undermining Global Stability', The New York Times, 
11 February 2007. https://www.nytimes.com/2007/02/11/world/ europe/11munich.html. Accessed 15 April 2020.

83. Robert M. Gates, Duty: Memoirs of a Secretary at War (New York: Vintage Books, 2015), 156.

84. Rice, No Higher Honor, 692.

85. Gates, Duty, 170.

86. Charles King, 'The Five-Day War', Foreign Affairs 87, no. 6 (2008): 211; and Stephen Sestanovich, 'What Has Moscow Done?' Foreign Affairs 87, no. 6 (2008): 12-28.

87. Hillary Rodham Clinton, Hard Choices (New York: Simon and Schuster, 2014), 236.

88. Stent, The Limits of Partnership, 212.

89. See Bill Browder, Red Notice: A True Story of High Finance, Murder, and One Man's Fight for Justice (New York: Simon and Schuster, 2015).

90. All quotes from official site of the President of Russia, 'Address by the President of the Russian Federation', 18 March 2014. http://eng.news. kremlin.ru/news/6889/print. Accessed 22 March 2014.

91. Edward Lucas, The New Cold War: Putin's Russia and the Threat to the West (New York: Palgrave Mcmillan, 2009); Robert Levgold, Return to Cold War (Cambridge: Polity Press, 2016).

92. Tsygankov, Russia and America, 5-7.

93. John Kerry, Every Day is Extra (New York: Simon and Schuster, 2018), 548-549.

94. One aspect of the closer relationship between Russia and Iran that is almost completely missed by analysts is expanding agricultural ties, witnessed by Iran signing a free trade agreement with the Eurasian Economic Union, bilateral memoranda of intent to increase agricultural trade and cooperation, and a rise in Iran's imports of Russian wheat.

95. John Bolton, The Room Where It Happened: A White House Memoir (New York: Simon and Schuster, 2020), 165.

96. Goskomstat, Rossiia v tsifrakh (Moscow: Goskomstat, 2003), 214, 378379.

97. The $\$ 1$ billion USD threshold is based on the export of consumeroriented agricultural products, intermediate commodities used for processing, and bulk commodities. It excludes agricultural-related commodities such as distilled spirits, ethanol, biodiesel, forest products, and fish products. See Table 6 for components of consumer-oriented agricultural products, intermediate commodities used for processing, and bulk commodities. These definitions are taken from the United States Department of Agriculture.

98. European Commission, 'Russia', n.d., https://webgate.ec.europa.eu/ isdb_results/factsheets/country/overview_russia_en.pdf. Accessed 9 May 2020; and European Commission, 'Agri-Food Trade Statistical 
Factsheet: European Union-Russia', 17 March 2020. https://ec.eur opa.eu/info/sites/info/files/food-farming-fisheries/farming/docume nts/agrifood-russia_en.pdf. Accessed 9 May 2020.

99. Wegren, Nikulin, and Trotsuk, Food Policy and Food Security, 54-61.

100. Author's calculations from data in Rosstat, Sel'skoe khoziaistvo, okhota $i$ okhotnich'e khoziaistva, lesovodstvo v Rossii 2004 (Moscow: Rosstat, 2004), 37; and Rosstat, Sel'skoe khoziaistvo, okhota $i$ okbotnich'e khoziaistva, lesovodstvo v Rossii 2009 (Moscow: Rosstat, 2009), 50.

\section{Selected Bibliography}

Albright, Madeline. Madam Secretary: A Memoir. New York: Harper Perennial, 2003.

Beschloss, Michael R. and Strobe Talbott. At the Highest Levels: The Inside Story of the End of the Cold War. Boston: Little, Brown and Co. 1993.

Blacker, Coit D. 'Military Forces'. In After Brezhnev: Sources of Soviet Conduct in the 1980s, ed. Robert F. Byrnes. Bloomington: Indiana University Press, $1983,125-85$.

Bolton, John. The Room Where It Happened: A White House Memoir. New York: Simon and Schuster, 2020.

Brada, Josef C. 'The Soviet-American Grain Agreement and the National Interest'. American Journal of Agricultural Economics, 65, no. 4 (November 1983): $651-56$.

Browder, Bill. Red Notice: A True Story of High Finance, Murder, and One Man's Fight for Justice. New York: Simon and Schuster, 2015.

Brown, Lester R. 'The U.S.-Soviet Food Connection'. Challenge, 25, no. 6 (January-February 1983): 40-49.

Clinton, Hillary Rodham. Hard Choices. New York: Simon and Schuster, 2014.

Christopher, Warren. Chances of a Lifetime: A Memoir. New York: Scribner, 2001.

Dobrynin, Anatoly. In Confidence. New York: Times Books, 1995.

Frost, Ellen L. and Angela E. Stent, 'Troubles with East-West Trade'. International Security 8, no. 1 (Summer 1983): 179-200.

Gaddis, John. 'The Evolution of U.S. Policy Goals Toward the USSR in the Postwar Era'. In Gorbachev's Russia and American Foreign Policy, eds. Seweryn Bialer and Michael Mandelbaum. Boulder: Westview Press, 1988, 305-313.

Garthoff, Raymond L. Détente and Confrontation: American-Soviet Relations From Nixon to Reagan. Washington, DC: The Brookings Institution, 1985.

Gates, Robert M. Duty: Memoirs of a Secretary at War. New York: Vintage Books, 2015. 
Gowa, Joanne. Allies, Adversaries, and International Trade. Princeton: Princeton University Press, 1994.

Hajda, Joseph. 'The Outlook for East-West Agricultural Trade'. In East-West Relations: Prospects for the 1980s, ed. Giuseppe Schiavone. New York: St. Martin's Press, 1982, 47-58.

Kerry, John. Every Day is Extra. New York: Simon and Schuster, 2018.

King, Charles. 'The Five-Day War'. Foreign Affairs 87, no. 6 (2008): 2-11.

Kissinger, Henry. White House Years. Boston: Little, Brown and Co., 1979.

Kozyrev, Andrei. 'Partnership of Cold Peace?' Foreign Policy no. 99 (Summer 1995): 3-14.

Levgold, Robert. Return to Cold War. Cambridge: Polity Press, 2016.

Liefert, William. 'Food Security in Russia: Economic Growth and Rising Incomes are Reducing Insecurity'. In Food Security Assessment, GFA-15, Economic Research Service, United States Department of Agriculture. Washington, DC: USDA, 2004, 35-43.

Lindsay, James L. 'Trade Sanctions as Policy Instruments: A Re-examination'. International Studies Quarterly 30 no. 2 (June 1986): 153-73.

Lucas, Edward. The New Cold War: Putin's Russia and the Threat to the West. New York: Palgrave Mcmillan, 2009.

Paarlberg, Robert L. 'The Soviet burden on the world food system: Challenge and response'. Food Policy l no. 5 (1976): 392-404.

Paarlberg, Robert L. 'Lessons of The Grain Embargo'. Foreign Affairs 59 no. 1 (Fall 1980): 144-62.

Paarlberg, Robert L. Food Trade and Foreign Policy: India, the Soviet Union, and the United States. Ithaca: Cornell University Press, 1985.

Petro, Nicolai N. and Alvin Z. Rubinstein. Russian Foreign Policy: From Empire to Nation-State. New York: Longman, 1997.

Pilcher, Jeffrey M. Food in World History, $2^{\text {nd }}$ edn. New York and London: Routledge Publishers, 2017.

Rice, Condoleeza. No Higher Honor: A Memoir of My Years in Washington. New York: Crown Publishers, 2011.

Riley, Barry. The Political History of American Food Aid: An Uneasy Benevolence. Oxford: Oxford University Press, 2017.

Rogov, Sergey M. 'The Changing Perspective of Russian-American Relations'. In From Rivalry to Cooperation: Russian and American Perspectives on the Post-Cold War Era, eds. Manus I. Midlarsky, John A. Vasquesz, and Peter V. Gladkov. New York: HarperCollins, 1994, 116-25.

Rumsfeld, Donald. Known and Unknown: A Memoir. New York: Penguin Group, 2011.

Sestanovich, Stephen. 'What Has Moscow Done?' Foreign Affairs 87, no. 6 (2008): 12-28. 
Shearman, Peter. 'Russian Foreign Policy Toward the United States'. In Russian Foreign Policy Since 1990, ed. Peter Shearman. Boulder: Westview Press, 1995, 111-33.

Stent, Angela E. The Limits of Partnership: U.S.-Russian Relations in the Twentyfirst Century. Princeton: Princeton University Press, 2014.

Trager, James. The Great Grain Robbery. New York: Ballantine Books, 1975.

Tsygankov, Andrei P. Russia and America: The Asymmetric Rivalry. Cambridge: Polity Press, 2019.

Tsygankov, Andrei P. Russia's Foreign Policy: Change and Continuity in National Identity, 4th ed. Lanham: Rowman and Littlefield, 2016.

VanGrasstek, Craig. Trade and American Leadership: The Paradoxes of Power and Wealth from Alexander Hamilton to Donald Trump. Cambridge: Cambridge University Press, 2019.

Wegren, Stephen K. 'Russian Agriculture and the WTO'. Problems of PostCommunism 54, no. 4 (2007): 46-59.

Wegren, Stephen K. Russia's Food Policies and Globalization. Lanham: Lexington Books, 2005.

Wegren, Stephen K. 'The Russian Food Problem: Domestic and Foreign Consequences'. Problems of Post-Communism 47, no. I (2000): 38-48.

Wegren, Stephen K. with Alexander Nikulin and Irina Trotsuk. Russia's Food Revolution: The Transformation of the Food System. London and New York: Routledge Publishers, 2021.

Wegren, Stephen K., Alexander Nikulin, and Irina Trotsuk. Food Policy and Food Security: Putting Food on the Russian Table. Lanham: Lexington Books, 2018.

Open Access This chapter is licensed under the terms of the Creative Commons Attribution 4.0 International License (http://creativecommons.org/licenses/ by $/ 4.0 /$ ), which permits use, sharing, adaptation, distribution and reproduction in any medium or format, as long as you give appropriate credit to the original author(s) and the source, provide a link to the Creative Commons license and indicate if changes were made.

The images or other third party material in this chapter are included in the chapter's Creative Commons license, unless indicated otherwise in a credit line to the material. If material is not included in the chapter's Creative Commons license and your intended use is not permitted by statutory regulation or exceeds the permitted use, you will need to obtain permission directly from the copyright holder.

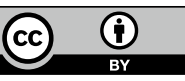

